NBER WORKING PAPER SERIES

BANKS IN THE MARKET FOR LIQUIDITY

\author{
Peter Garber \\ Steven Weisbrod
}

Working Paper No. 3381

NATIONAL BUREAU OF ECONOMIC RESEARCH

1050 Massachusetts Avenue

Cambridge, MA 02138

June 1990

This paper is part of NBER's research program in Financial Markets and Monetary Economics. Any opinions expressed are those of the authors and not those of the National Bureau of Economic Research. 
NBER Working Paper \#3381

June 1990

\section{BANKS IN THE MARKET FOR LIQUIDITY}

\section{ABSTRACT}

Banks are unique among financial institutions because they are the cheapest source of liquidity in the economy. Banks choose to hold reserves to facilitate settlement of end-of-day net due to positions arising from payments operations. Money market substitutes for bank liabilities do not escape from the cost of reserves since their issuers lean on banks to provide liquidity. Since the cost of reserves falls on all issuers of less liquid liabilities seeking access to payment services, including non-bank intermediaries, reserves cannot represent a tax on the banking system alone.

Peter Garber

Department of Economics

Brown University

Providence, RI 02912
Steven Weisbrod

Weisbrod Group Ltd.

114 E. 32 Street

Sulte 1306

New York, NY 10016 
In recent literature on the role of banks in financial markets, the ascendent perspective has focused on banks' special information about borrowers relative to that of other financial institutions. 1 For example, Fama (1985) presented evidence that commercial paper, bankers' acceptances, and bank certificates of deposit trade at the same yields. Banks must hold reserves against deposits, which most researchers interpret as a tax paid by bank customers. $^{2}$ Because commercial paper does not have a reserve requirement, Fama inferred that depositors do not pay for reserves. He concluded that the tax incidence falls on customers who borrow from banks and that therefore bank loans are a unique form of credit. Otherwise, borrowers would switch to an untaxed source of credit. 3

Such observations have generated assumptions that banks have private information about customers unavailable to other, non-bank lenders. Little effort has been expended, however, to detail the

1 For a recent review of this literature and of other perspectives on the role of banks, see Gertler (1987).

2 For example, see Black (1975) for such an interpretation. James (1987) confirms Fama's evidences on insignificant spreads between certificates of deposit and commercial paper, showing that the average spread remained unchanged across changes in reserve
requirements.

3 James (1987) developed additional evidence that capital markets regard banks as possessors of private information about borrowers not available to other lenders. He found that the announcement of a bank line of credit causes the stock of the recipient company to exhibit excess returns immediately after the announcement. In contrast, he found that the announcement of a commitment to lend by an insurance company causes no such reaction in the stock market. Lummer and Mcconnell (1989) found that James's results hold only when existing bank lines are renewed. 
sources of such superior bank information. 4

In these pages, we consider an explanation of why banks are unique among financial intermediaries which does not lean on an informational advantage. Banks are unique because they are the cheapest source of liquidity in the economy. This advantage is not derived from the special nature of individual banks but from the special nature of the banking system which can mobilize good funds more easily than competing financial institutions. 5 when a cash in advance requirement materializes for some transaction, a bank must make the market by delivering a bank deposit.

We develop this liquidity concept by presenting a basic image of the commercial paper market in which issuers may be forced to depend on bank loans to guarantee delivery of cash to investors when their paper matures. Issuers in such wholesale markets obtain

4 Black (1975) and Goodfriend (1988) have suggested that banks obtain their special information because of their role in the payments system. They argue that a bank benefits from having a demand deposit relationship with a customer which provides it with current information about the state of the borrower's financial condition. Another non-bank lender, however, could easily erode this competitive advantage by requesting that the borrower provide real time access to his on line bank financial statements.

Goodfriend also argues that since banks must lend to each other on short notice, they develop skills for quick credit evaluation. These skills are then transferable to customer examination.

There may be economies for a potential borrower to subject itself to a bank credit examination because the borrower must visit the bank anyway to access the payment system. After having done the examination, the bank knows more than other lenders ex post: but ex ante it has no intrinsic advantage in information gathering.

5 "Good funds" can mean either cash or, more typically in the wholesale markets we examine, deposits at the Federal Reserve or at banks, items whose delivery always constitutes settlement of a claim for dollars. 
assurance of access to bank loans by establishing a line of credit with a bank. If the line is used, the bank must issue a demand deposit and obtain reserves. To guarantee that it will have reserves, the bank holds reserves against the unused line. Under this scenario, participants in the commercial paper market bear part of the cost of the bank's reserves, the price paid for making commercial paper liquid. In a more realistic commercial paper market where reserves are not held directly against an unused line, anyone demanding liquidity for commercial paper will still pay for the cost of reserves in the banking system. We extend our argument further across the balance sheets of banks by explaining how banks can hold commercial and industrial loans in the absence of an informational advantage.

Analogous to the relation between commercial paper and certificates of deposit, demand deposits and Federal funds loans are substitutes. Holders of neither instrument bears the cost of reserve requirements against demand deposits. Rather, holders and issuers of less liquid assets requiring periodic settlement in demand deposits bear the costs. Any wholesale borrower or lender demanding liquidity is directly or indirectly a potential bank customer acquiring similar services from the bank. The standard explanation treats borrowers and depositors at banks as different groups making essentially different decisions.

Finally, we study the sense in which reserves can possibly be a tax on the banking system rather than a cost of accessing payment services paid by less liquid securities markets. Generally, it is 
difficult to determine the incidence of any tax because the entity directly paying the tax typically passes the cost through to its customers. Bank customers dealing in the wholesale money markets considered here channel their direct costs of bank services to their ultimate clients, the issuers and buyers of securities less liquid than bank deposits.

Indeed, since reserves provide a service, reserve requirements are not necessarily a tax. Reserves cover the costs and risks assumed by the clearing mechanism, generally a central bank. If reserve requirements exceed those needed to cover the risk of the central bank, however, reserves do represent a tax; but the costs will be borne by all users of liquidity. If there are nonreservable perfect substitutes for each class of bank deposits, reserve requirements cannot be excessive; banks will adjust their reservable deposits to match their desired reserve holdings.

\section{Who Pays for Reserve Requirements?}

We begin this analysis with the now conventional scenario of who pays for reserve requirements. In Figure 1, the vertical axis represents the interest rate paid on bank deposits or earned on loans by banks, holding other interest rates in the economy constant. The supply of deposits to the banking system is perfectly elastic at interest rate $r$. The cost of reserve requirements, the foregone interest on reserve holdings at the central bank, is represented in Figure 1 by the difference between the dashed line and the supply curve of deposits. The demand for 
bank loans is downward sloping.

The shape of the supply curve of deposits in Figure 1 indicates that investors' portfolios contain perfect substitutes for bank deposits. Investors are unwilling to earn a lower yield on bank deposits than on the perfect substitute, which is exempt from reserve requirements. As a result, depositors will not bear the cost of reserves.

Non-bank loans are not perfect substitutes for bank loans. If the interest rate on bank loans rises relative to rates on other credit market instruments, bank borrowers will continue to demand bank loans, though in reduced amounts. Borrowers then bear the cost of reserves in Figure 1 .

Are There Perfect Substitutes for Bank Deposits?

Commercial paper offers an alternative short-term investment to bank certificates of deposit. Like a bank deposit, it promises to deliver good funds at maturity; but since commercial paper is not a bank liability, it does not have a reserve requirement. Commercial paper issued by creditworthy corporations in the United States trades at the same yield on average as bank $C D .{ }^{6}$ Bank $C D$, like commercial paper, is negotiable, so both instruments can be sold to other parties before maturity. Alternatively, both can be used as collateral to obtain bank loans.

That commercial paper and certificates of deposits trade at the same yields indicates that they have the same liquidity and risk characteristics. From this evidence of substitutability and

6 This was shown in Fama's (1985), Table 1. 
the graphical analysis of Figure 1, we should infer that the cost of reserves is paid by bank borrowers and not by bank depositors. From this conclusion arises the assumption that banks are special because they have access to special information about borrowers that cannot be equally well gathered by a non-bank lender.

\section{Commercial Paper Issuers obtain Credit Lines from Banks}

This reasoning, however, ignores an important element in the commercial paper market: corporations which issue commercial paper maintain credit lines, representing the right to borrow good funds from a bank during a certain period. 7 Credit lines give commercial paper issuers access to the liquidity of the banking system. Commercial paper issuers sometimes require bank loans to pay off their commercial paper; as occasional bank borrowers themselves, they must also pay for reserves according to the conventional view that bank borrowers pay for reserves.

\section{Banks as Market Makers in Liquidity}

Access to good funds makes banks suppliers of cash to commercial paper issuers. Since any financial institution can hold

7 We have been purposeful in maintaining this oversight to mimic the analysis of the current banking literature. Fama (1985) discusses lines of credit but only as a device for periodically triggering a bank's assessment of the company. In practice, banks do not generally back up their credit assessment with a guaranteed loan, however; the line is conditional on no material change in the financial standing of the company. Hence, the bank making a commitment of a line needs to know no more about its customer than other financial intermediaries know. 
good funds in the form of a currency inventory, it is useful to explore the organization of the banking system to understand why banks are the lowest cost market maker in good funds.

Banks hold a small percentage of their assets in good funds. Individual banks can make a credible statement about delivering good funds to their deposit customers and borrowers on demand because banks are part of a banking system, tied together by the clearing and settlement mechanism of a clearinghouse. Members agree to lend good funds to members who experience a drain on good funds on any particular day, i.e. to banks whose market making activities in good funds cause them to have end of day net debit positions from large volumes of payment orders. 8

\section{A Clearinghouse system}

We now examine the organization of a clearinghouse and the effects of different conventions of clearing and settlement. Though most of the following is well-known, it emphasizes the advantage that a clearing and settlement system gives to banks in the market for good funds.

\section{Payments with Continuous settlement}

Final settlement of payments among banks occurs with the delivery of good funds. 9 In a system of continuous settlement,

8 Whenever a deposit is cashed or a loan is made, a bank becomes a buyer of good funds at a posted bid price because it must make delivery of funds to a customer or another bank. Whenever a loan is repaid or a deposit is made, a bank becomes a seller of good funds at a posted offer price.

9 of course, settlement may be in any mutually acceptible medium. In actual banking systems, settlement is not final unless payment is made in good funds--currency or central bank deposits. 
each payment message from one bank to another is accompanied by the good funds specified in the message. As long as the sending bank has sufficient reserves on hand, payments messages will be processed without delay. In continuous settlements, receiving banks bear no credit risk from participating in the payment mechanism.

In a continuous settlement system, when the amount of payment exceeds the good funds on hand, the payment must be blocked until more funds are received. If numerous banks face a similar situation, the payments system can become gridlocked. Banks wish to make large payments to each other but cannot send payments because they have not received payments. Thus, a system of continuous settlement dispels credit risk among banks from the day's payments by reducing the potential speed of transmitting payments. That is, it reduces risk by reducing liquidity.

The gridlock problem can be solved by breaking up payment orders into smaller parts. This increases the payment traffic on the communication system and may result in incomplete delivery of agreed values, thereby creating credit risk. Alternatively, the banks can generally increase their reserve holdings. This would involve selling loans to other investors in return for good funds. Bank customers would have to pass through a higher cost of reserves.

Whether this arises through legal constraints or through choice is not at issue here. 


\section{Periodic Net Settlement}

To avoid breaking up transactions or increasing reserves, banks can engage in net settlement at the end of the day. They would pay the difference between total payments and total receipts at the end of the day, forming a clearinghouse for the purpose of executing the net settlement. All good funds held by banks would be transferred to the clearinghouse to collateralize bank payment orders.

Banks can execute delivery of good funds without increasing their reserves because the individual members of the clearinghouse and their customers believe that net due to positions cumulating during the day will be covered by delivery of good funds at settlement. Members are justified in their belief if the clearinghouse guarantees due to's and holds reserves exceeding the sum of the net due to exposures to the clearinghouse that crop up between settlement periods.

In a private clearinghouse system reserves are not a tax; rather, they are the cost of providing assurance that good funds will be delivered to banks for their net due to positions. The clearinghouse does not insure that all the deposits in an individual bank will be treated as cash settlement by the market place, but it does guarantee that good funds will be delivered for payment orders among banks. 10 To the extent that the guarantee

10 In settling net positions, the clearinghouse makes a claim that in the event that one member is in bankruptcy, it has the right to offset payments due from that member with payments due to that member. The clearinghouse makes prior claim over all other creditors to the bankrupt member's liabilities to the clearinghouse 
is credible, a depositor can treat bank payment orders to its account during the day as good funds.

\section{The Role of the Federal Reserve}

The Federal Reserve is a clearinghouse with the power to create good funds by purchasing government or private securities. The Fed's power freely to create reserves does not obviate reserves as a source of liquidity. Nor does this power make reserves a tax, as in the conventional interpretation. The Fed bears the same risk of settlement failure as the private clearinghouse: reserves serve as a guarantee to the fed of the delivery of good funds against end-of-day net due to positions.

In Fedwire payments, banks with net positions due their reserve account at settlement borrow Fed funds from other members. The Federal Reserve guarantees unconditionally that a bank payment message sent over Fedwire will be honored as good funds at settlement. If a bank fails to deliver good funds, the Fed supplies them without assessing other banks for the deficit in reserves resulting from the failure. During the day, the Fed then insures the market in wholesale payments. Hence, the revenue on reserves deposited with the Fed serves as a compensation for the

to the extent that they are offset by that member's loans to the clearinghouse. Much of the security the clearinghouse adds to the payments mechanism is derived from liability rules. Reserve requirements protect the payments mechanism in a similar fashion. They are assets of the several member banks, but the clearinghouse has prior claim to them in the event of bankruptcy. 
risk it bears. 11

The inter-connection among banks and their connection to the central bank permits the quick movement of good funds from banks with a surplus of good funds to deficit banks. Of course, non-bank institutions could establish similar networks and supply similar assets and liabilities, but this would effectively make them banks, though lacking in payment insurance. That banks can turn to the central bank for funds, however, makes it certain that their net due to's issued between settlement periods will be settled in good funds, while the net due to's of other financial institutions lack such guarantees.

Aside from operational expense, the cost to the banks of the liquidity provided to borrowers and depositors through access to the banking system is the forgone interest on the reserves banks hold with the central bank to guarantee liquidity. Other financial institutions are not required by regulators to bear this cost, and they typically do not form independent organizations which impose reserve requirements on members. 12 If banks alone are forced to

11 The Fed may or may not earn a profit from the user charge represented by reserves, depending on its magnitude. Moreover, there may be more efficient means of charging for this risk bearing. Since the Treasury taxes the Fed's revenues, it ultimately bears the risk of operating the payment system.

12 In the U. S., any depository institution which offers transaction accounts, that is, deposits which permit third party payments services, must hold reserves with the Federal Reserve. The role of non-banks in wholesale payments is very small, however. clearinghouses in organized financial markets provide liquidity services for members and do regulate member liquidity, but ultimately they rely on the banking system for the delivery of good funds to cover net positions. 
hold reserves and membership in a central banking system has no offsetting value, banks would go out of business because no investor or borrower would be willing to pay for the reserves. The banking system gives banks the advantage of providing to potential borrowers a credible guarantee of delivery of good funds without holding reserves on their balance sheets to cover all lines.

\section{Pricing a Line of credit: A Basic view}

Commercial paper issuers attach a line because they must assure lenders that they can deliver good funds at maturity. Normally, issuers can obtain funds by reissuing or rolling over commercial paper; during times of liquidity stress in the money markets, however, it is difficult for even high quality borrows to issue short-term paper. Even in normal times, a CP issuer may face technical problems in rolling over its paper. A cash delivery can be assured only by buying a line from a bank which in turn has access to the banking system and to the liquidity services of the central bank.

We will see that commercial paper holders must bear some of the issuer's cost of accessing bank liquidity and that the cost of using a line is related to the cost of reserve requirements. To analyze these claims, we examine the banking transactions involved with maturing $C D$ and $C P$.

\section{A Certificate of Deposit Matures}

In Table 1 we illustrate the impact of a maturing deposit on the balance sheet of a banking system consisting of two banks. 
Consider banks $A$ and $B$ in Table 1a. As assets, bank A has $\$ 900$ of loans on the asset side and $\$ 100$ of reserves. It funds these assets with a $\$ 100$ certificate of deposit and $\$ 900$ of demand deposits. Suppose that banks by convention hold 10 percent reserves against demand deposits but can choose any level of reserves against $C D$, so bank $A$ holds "excess reserves" of $\$ 10$ which, as we will see, guarantees the liquidity of the CD. Bank $B$ has loans of $\$ 540$, reserves of $\$ 60$ and $\$ 600$ of demand deposits.

Now let us assume that the $C D$ on Bank $A^{\prime}$ 's balance sheet matures. The holder of that deposit uses the funds to pay a debt to a customer of bank B, who, in turn, buys a demand deposit (DD) from bank $B$ with the funds. The customers of the banking system as a whole then do not roll over the $C D$ but require settlement in demand deposits. If they are always willing to roll over the $C D$, the existence of $\mathrm{CD}$ would place no liquidity demands on the system. Occasional demands to settle $C D$ in demand deposits make $C D$ somewhat illiquid.

If the system settles at end-of-day, in the first instant the payment order appears on B's books as a due from $A$ of $\$ 100$ and an addition to demand deposits of $\$ 100$. On the other hand, if this is a private continuous settlement system, $A$ would send $\$ 100$ in reserves.

Bank A still has $\$ 900$ of loans which it funds with $\$ 900$ in demand deposits. It settles its payment with the delivery of $\$ 100$ in reserves to bank $B$, so its reserves were sufficient to cover its end-of-day net due to position. Bank A may feel that its position 
is not balanced because it may not have sufficient reserves to process further payments next day. Suppose that A considers $\$ 90$ in reserves sufficient to operate its payment services. In the interbank market, bank A borrows $\$ 90$ from B so that B now has a due from $A$ on the asset side of its balance sheet, and $A$ has a due to $B$ on the liability side of its balance sheet. The final positions of banks $A$ and $B$ are illustrated in Table 1b. The $C D$ was liquid because bank A could guarantee the delivery of good funds through its reserve holdings and its ready access to interbank loans. Reserves on hand also guaranteed liquidity by effecting a transfer among banks of the credit risk arising from the day's payments traffic

\section{Commercial Paper Matures}

Suppose now that the investor who held a $C D$ in bank $A$ in the previous example holds commercial paper instead. The holder of the $C P$ is a customer of bank $B$. Since commercial paper is the direct liability of a borrower, both loans and $C D$ are initially $\$ 100$ less than in the previous example. The issuer of $C P$, however, arranges a line of credit from bank $A$ to assure payment at maturity.

The initial positions of banks $A$ and $B$ are presented in Table 2a. Bank $A$ has a credit line for $\$ 100$ to the commercial paper issuer. Appearing as a memo'item, this line represents a potential liability because bank A must raise a liability if the line is used.

Suppose that the CP issuer cannot roll over the paper when the 
$C P$ matures. The issuer of the CP, calling on his line, takes a loan from bank $A$ to pay the customer of bank $B$. The customer of bank $B$ again buys a DD from his bank with the funds. The balance sheets of the two banks up to this point are illustrated in Table 2b. Bank A's assets consist of its original $\$ 800$ in loans plus its new $\$ 100$ loan to the CP issuer. Bank B's DD liabilities have increased by $\$ 100$. The accounts of the two banks are balanced through the use of due to's and due from's if settlement is at end of day. If settlement is continuous, balancing occurs through a delivery of reserves. With a clearinghouse or with a central bank bearing payment system risk, bank $A$ will have to restore its reserve position to cover the risk to the payment system on the next day's transactions. Bank $A$ borrows $\$ 90$ in the interbank market to leave the end-of-day position of the banking system as in 2c. As an effect of these transactions, bank assets and liabilities have been substituted for the maturing commercial paper.

\section{Holding Reserves Aqainst a Line}

Again, raising the $D D$ in bank $B$ generates a use of reserves for settlement directly connected to providing liquidity to commercial paper. Bank B cannot expand its demand deposits carried overnight without increasing its reserves by $\$ 10$ because it must cover its greater potential next day net due to position. Bank A can satisfy its commitment to the $C P$ issuer by holding sufficient good funds as reserves on its balance sheet to cover the increased reserve holdings on the DD generated when the issue matures. Bank 
A knows that the delivery of $\$ 10$ in good funds plus $\$ 90$ of due to's will satisfy its credit commitment to the $C P$ issuer, while still allowing it to serve the potential next day payment needs of its remaining DD customers. ${ }^{13}$ More generally, bank A need not hold the additional reserves directly, as long as they are available somewhere in the banking system.

The Price of the Line of credit and the cost of Holding Reserves

In this example, the reserves held against the $C P$ and $C D$ are equivalent. If bank $A$ holds $\$ 10$ in additional reserves to cover its liquidity commitment on its customer's line, the opportunity cost will be covered in the price of the line on the commercial paper. The CP issuer will offer a commensurably lower yield to cover this cost of providing liquidity, so the CP holder bears the cost of reserves needed in the payments mechanism to provide liquidity. Both short-term and liquid, $C P$ and $C D$ are perfect substitutes; and they should therefore pay the same yields, as confirmed by Fama. Both depend on the holding of good funds as reserves against demand deposits to assure liquidity, however, so both pay for the cost of such reserves.

This stark example is not a realistic view of the CP market, however. As members of a banking system, individual banks can provide lines without actually holding reserves. They can provide liquidity to non-bank securities at a much lower cost than our

13 If settlement in bank claims alone were sufficient to operate the payment system, there would be no need for reserves. Reserve holdings even in a private clearing system provide the most liquid collateral for participants. 
example would imply. We will show below that the effect of a banking system's ability to economize on reserve holdings does not change the incidence of the cost of reserves.

\section{The cost of Liquidity: A More Realistic Commercial Paper Market}

In our simple commercial paper example, we concluded that both $C P$ and $C D$ holders pay for reserves. We consider again a commercial paper market in which issuers hold bank lines to assure the delivery of good funds to investors at maturity. If the line is used, a loan is created to deliver funds to the CP holder's bank. The issuance of the loan creates a due to position to the CP holder's bank which must be funded with a deposit. Since the Federal Reserve guarantees that the due to will be converted to good funds at settlement, reserves need not be held against the line to guarantee that a deposit can be created to fund the loan. If the deposit is issued, reserves must be found by the end of the day, however. We will discuss in detail how the costs of reserves are split. First, we determine the costs borne by the CP buyer. Then we consider costs borne by the CP issuer.

\section{The CP Buyer's Cost of Bank Liquidity}

Suppose that the commercial paper issuer faces a probability of .1 of borrowing from a bank at the maturity of the $C P$ in five business days. The $C P$ issuer expects to use a bank loan only overnight at maturity, if at all. As an alternative to issuing $C P$ 
with a line, he can issue a liability of the same maturity without a liquidity guarantee. He would issue the less liquid liability if he could sell it at an interest expense greater than the explicit interest expense on the $\mathrm{CP}$ by no more than the expected additional cost of the bank loan plus the up-front cost of the line.

Assume that the interest rate in the inter-bank Fed funds market is 10 percent and the reserve ratio against demand deposits is 10 percent. Since the bank can sell reserves in the Fed funds market, its opportunity cost of reserves is an annualized one percent of the deposits that it must raise to fund its loans.

The $C P$ issuer's expected annualized cost of reserves is $1 / 5 \mathrm{x}$ $1 / 10 \times 1$ percent or 2 basis points. The issuer faces a ten percent probability of using a bank loan once every five days. He will issue commercial paper backed by a credit line rather than a less liquid liability if he can obtain at least a two basis point reduction in his annual interest rate for doing so. The $\underline{\mathrm{CP} \text { buyer }}$ in this case will accept a two basis point reduction from the yield on less liquid paper, such as the same paper without a bank line.

\section{The CD Buyer's Cost of Bank Liquidity}

To determine the cost of reserves to the $C D$ holder, we must consider whether $C D$ can substitute for $C P$ in an illiquid market in which CP generally cannot be rolled over. Actually having the same liquidity characteristics indicates that the two instruments are affected similarly when the market demands delivery of cash. If the delivery of a $C D$ is accepted as settlement when the delivery of 
$C P$ generally is not accepted, $C D$ must be more liquid than $C P$ and therefore must trade at a lower yield.

Accepting the evidence indicating that $C D$ and $C P$ are equally liquid, we presume in completing this example the extreme case that investors reluctant to hold $\mathrm{CP}$ also shun $\mathrm{CD} .^{14}$ In this case, a demand for cash payment requires settlement with a demand deposit, which always maintains its value in good funds. If holders of both $\mathrm{CP}$ and $\mathrm{CD}$ require delivery of a demand deposit in a liquidity crunch, they must both pay for the reserve holdings against demand deposits when either the bank issuing $C D$ or the corporation issuing $C P$ cannot roll over these liabilities. In this case, holders of both instruments pay for the expectation that investors will require a demand deposit at settlement, and their yields are less than the yield of a less liquid instrument by the expected cost of holding reserves on demand deposits.

\section{The CP Issuer's Cost of Bank Liquidity: The Role of the Dealer}

The analysis of the incidence of reserve costs is not yet complete because the holder of $C P$ or $C D$ may wish to sell the security before maturity. Assume that the investor sells to a dealer who in circumstances of illiquidity in $C P$ and $C D$ markets cannot sell the security under a repurchase agreement to finance inventory. The dealer must then finance with a bank loan which, in turn, must be financed by the issue of a demand deposit, given that

14 More generally, the $\mathrm{CP}$ of an individual firm may not roll over even though there is no general CP crisis. The bank loan may then be funded with $C D$. 
the $C P$ and $C D$ markets are not then liquid.

since the $C P$ or $C D$ has not matured, it must be sold at a discount today. The discount must be greater than normal by the cost of the reserves, which represents an additional funding cost for the dealer. ${ }^{15}$ We assume again that interest rate on Fed funds is 10 percent and that the reserve ratio against $D D$ is 10 percent, so the cost of reserves will be an annualized 1 percent of demand deposit funding.

As before, we assume that with a probability of .1 , the $C P$ or $C D$ cannot be sold before maturity without bank funding to the dealer and that five days remain until maturity. On issue, the investor must be compensated for the expected extra cost of illiquidity in the $C P$ and $C D$ markets, i.e. the extra haircut administered by the dealer to cover the reserve cost of his bank loan. We assume an equal probability that the paper cannot be sold on any of the four days before maturity. On an annualized basis, the expected cost of liquidity of a sale before maturity is $4 / 5 \mathrm{x}$ $1 / 10 \times 1$ percent, or 8 basis points. The investor is then paid 8 basis points above the rate of return on Fed funds. 16

15 This analysis presumes that there is an ample number of dealers with well-prepared bank lines. If not, there is an even greater illiquidity due to the limited capacity of individual dealers to bear risk. See Grossman and Miller (1989) on this issue.

16 It is not necessary for all investors to sell their CP and $\mathrm{CD}$ for demand deposits in a liquidity crunch. As in all markets, the demands of the marginal investor determine the price. The eight basis points is the incremental return required to make the marginal investor willing to bear the risk of a decline in the value of his security relative to good funds in a crunch, whether he sells his security or not. 
The liquidity crunch requiring the raising of a demand deposit occurs with probability . I spread evenly over the time to maturity of the paper. The total expected cost of reserves generated by loans providing liquidity to $C P$ is then ten basis points $(1 / 10 \times 1$ percent). If the CP buyer were to pay this expected cost entirely, the issuer would have to compensate him by offering a yield 10 basis points above Fed funds. The issuer, however, achieves a 2 basis point lower yield because the market is virtually certain that he can deliver cash in five days at the maturity of the paper. He expects to pay for this two basis point reduction in the form of the cost of reserves. Prior to maturity, the buyer must be compensated for the possibility that he might have to sell to a dealer who must finance inventory with a bank loan. For this, the buyer must receive an 8 basis point higher interest rate, compared to Fed funds. The issuer pays $4 / 5$ of the cost (the higher interest rate paid to the buyer), and the buyer pays $1 / 5$ of the cost of constantly providing liquidity to the $\mathrm{CP}$.

The expected cost of reserves can take the form of an up front fee for a line or a premium over the overnight inter-bank rate. If the cost is paid as a fee, both issuers and purchasers of CP pay the expected price for bank line use. If it is paid as a premium, the full cost is borne by the actual users of lines, i.e. either by the issuer or by the buyer of the paper in costs passed through the dealer. 


\section{Who Pays the cost of Reserves on CD's? The Market for less}

\section{Liquid Securities}

In section 4 we described a liquidity problem in which the marginal investor wanted to convert his $C P$ or $C D$ into a demand deposit. We now consider less severe liquidity problems that may affect less liquid financial instruments than $C D^{\prime} s$ and $C P$ 's. We will refer to the more severe crisis in which only demand deposits are acceptable as a DD crisis and to the less severe liquidity problem as a $\mathrm{CD} / \mathrm{CP}$ crisis. During such liquidity problems, investors attempt to convert their less liquid financial instruments into $\mathrm{CD}^{\prime} \mathrm{s}$ or $\mathrm{CP}^{\prime} \mathrm{s}$. In this milder form of liquidity problem, $C P$ and $C D$ holders do not demand to convert their holdings into demand deposits.

We assume, as before, that the Fed funds rate is 10 percent and that banks hold a 10 percent reserve ratio against demand deposits. In addition, we assume that the reserve ratio on bank $C D$ 's is 3 percent and that the less liquid security has the same five day maturity as the $C P$ in our previous example.17 The probability of a $\mathrm{CD} / \mathrm{CP}$ liquidity crisis on any day is 0.2 . The probability of a DD liquidity crisis on any day is 0.1 , as before. The occurrence of the two types of crisis is mutually exclusive.

How does the cost of liquidity affect the market for the less liquid instrument? At maturity, the issuer of the less liquid instrument faces a probability of $3 / 10$ that he cannot roll over

17 This ratio would reflect the $C D^{\prime}$ 's effect on the bank's potential net due to's from a day's transactions. 
his security and must fund with a bank loan. When this happens, the bank can fund the loan with a $C D$ with probability $2 / 3$; with a probability of $1 / 3$, it must issue a demand deposit.

By taking out a bank line to guarantee delivery of whichever bank deposit is demanded in settlement, the issuer faces part of the expected cost for reserves generated by the security. This expected cost consists of two components: $1 / 5 \times 30$ basis points is the expected cost of a mild liquidity problem and $1 / 10 \times 100$ basis points is the expected cost of a major liquidity crisis. The total expected cost of bank liquidity is then $1 / 5 \times 30+1 / 10 \times 100$ or 16 basis points. Since he refunds his security once every five days, the issuer's expected cost in terms of an annualized liquidity premium is $1 / 5 \times 16$ or 3.2 basis points. He is willing to issue a security backed by a line if he can achieve a 3.2 basis point reduction in interest expense for doing so.

The holder of the security faces an expected cost of reserves in selling to a dealer in a crisis. In a mild crisis, the dealer funds with a bank loan issued against a CD. The cost is $1 / 5 \times 30$. In a severe crisis, the bank loan is funded with a demand deposit. The cost is $1 / 10 \times 100$. The total expected cost is absorbed between issuance and maturity -- that is, for four out of five days. Thus, the expected cost of reserves borne by the holder is $4 / 5 \times 16$ basis points or 12.8 basis points. The holder must be paid 12.8 basis points over the Fed funds rate to be content to hold the less liquid security.

The cost of reserves on CD's will be split between the issuer 
of a security less liquid than a $C D$ and the holder of the security. The expected cost of reserves on a $C D$ is $1 / 5 \times 30$ or 6 basis points. The holder pays an expected 1.2 basis points in terms of accepting a lower yield than on the same security without a bank Iine. The issuer pays an expected 4.8 basis points in terms of a higher yield to compensate the investor for the cost of selling in a mild crisis.

\section{The Commercial and Industrial Loan Market}

Consider a potential issuer whose security is so illiquid that if it were sold on a security market, a dealer would always have to fund his purchase with a bank loan. The security is also so illiquid that it certainly cannot be rolled over at maturity -- a bank loan is surely required to deliver cash at maturity. We shall show that the potential holder and issuer of this security face an expected cost of reserves equal to the actual cost of reserves against such a security held directly by a bank. No incentive then arises to hold this security off a bank balance sheet.

Suppose that the Fed funds rate is 10 percent, the reserve ratio on a demand deposit is 10 percent, and the reserve ratio on a $C D$ is 3 percent. For now we assume that the security is held by a non-bank lender, that it matures in five days, and that it is affected by a DD crisis in the same way as all other securities. With probability .1, investors will attempt to sell these securities for demand deposits before maturity or the issuer will have to deliver demand deposits at maturity. The C\&I loan, 
however, is in a constant state of mild liquidity crisis. If an investor were to sell the security, it would always have to be bought by a dealer funded by $C D$, except in a DD crisis. Similarly, issuers must always borrow from a bank at maturity funded by $C D$ except in a DD crisis.

When he takes out a bank line, the issuer knows he must borrow at maturity. His expected cost of reserves is $1 / 10 \times 100$ basis points to cover the expected cost of delivery of demand deposits. It is $9 / 10 \times 30$ basis points to cover the expected cost of delivery of a $\mathrm{CD}$. Since the security matures every five days, his expected cost of reserves is $1 / 5 \times 1 / 10 \times 100$ basis points plus $1 / 5 \times 9 / 10$ $x 30$ basis points $=7.4$ basis points. He will take out a bank line if he can issue his security for 7.4 basis points less than he would have had he not obtained a bank line.

The holder of the security must be compensated for the expected dealer financing costs. These costs are $1 / 10 \times 100$ basis points for the expected cost of the delivery of a demand deposit, and $9 / 10 \times 30$ basis points for the expected cost of the delivery of the CD. The holder faces these costs over 4 days. Thus, his total expected cost is $4 / 5 \times 1 / 10 \times 100$ basis points plus $4 / 5 \times 9 / 10 \times 30$ basis points $=29.6$ basis points. The holder will hold this security only if he can earn 29.6 basis points above the Fed funds rate.

The total expected cost of reserves is 37 basis points. Given the market's expectation of liquidity crises, a bank can expect to fund itself with 90 percent $C D^{\prime}$ s and 10 percent demand deposits. 
The expected cost of the reserve burden facing the bank is thus .9 x 30 basis points plus .1 x 100 basis points $=37$ basis points. The expected cost of reserves in the C\&I market exactly equals the cost of reserves facing the bank. 18

\section{The Fed Funds Market and the Burden of Reserves}

We have used the Fed funds rate as our benchmark liquid interest rate. Fed funds obligations are effectively guaranteed settlement in good funds since the Fed provides intra-day and limited overnight lines to Fed fund borrowers. The properties of bank demand deposits held overnight are identical to those of Fed funds: both represent instant next-morning access to good funds. As in Fama's examples of the close substitutes $C D$ and $C P$, the yield on Fed funds should then approximate the implicit yield on demand deposits. Yet, a bank funding itself with demand deposits bears a reserve requirement while a bank funding itself with Fed funds does not. Since a bank borrowing Fed funds typically must acquire them from a bank which funds itself with demand deposits or with $C D$ which require reserves, it is conventionally presumed that Fed funds yields bear a markup over implicit demand deposit yields and $C D$ yields by the cost of reserves. We will now show that, on the contrary, the Fed funds and effective yields on demand deposit

18 We note that lender and borrower share the burden of reserves in the ratio of 4 to 1 , which is determined by the maturity characteristics of the note. In a more complete model, the maturity characteristics would be endogenously determined. If borrowers bore the burden of more frequent cash verification, lenders would pay a higher percentage of the reserve burden. 
rates should be equal and that both rates should be lower than $y$ ields on $C D$ and $C P$.

A Conventional View of the Relation Between Fed Funds and $C D$ Rates

This conclusion is contrary to the following standard argument that the Fed funds rate should equal the $C D$ rate plus the interest cost of reserves.19 At settlement, a bank with a net due to position cumulated during the day has two means of acquiring funds through raising liabilities. It can either purchase Fed funds or sell a deposit. We presume that $C D$ rates are the marginal cost of bank funds. 20 If it sells a $C D$, it creates a due from the bank of the party purchasing the $C D$, which will decrease the selling bank's own end-of-day net due to position. If it purchases Fed funds, it settles a due to position directly through interbank transactions alone. Either transaction will increase the bank's reserve account balance.

Reserves must be held against $C D$, however, while no reserves are required against Fed funds. Since banks would apparently gain by avoiding the cost of reserves, banks should have an incentive to bid the Fed funds rate above the $C D$ rate by the cost of reserve requirements. The effective $C D$ rate, the $C D$ rate divided by .97 , would equal the Fed funds rate.

That this does not happen is illustrated in Table 3 . We compare the average daily Fed funds rate with the average daily one

19 For example, see Moore et al. (1988).

20 The argument would apply to implicit DD rates if DD is the marginal source of funds. The Fed funds rate would then exceed the DD rate by the cost of reserves. 
month domestic $C D$ rate over the period 1980 through 1988 . Over the entire period, the Fed funds rate was an average of 13 basis points above the $C D$ rate. Correcting for reserve requirements by dividing the $C D$ rate by .97 , the effective $C D$ rate was 18 basis points above the Fed funds rate.

$C D$ 's are of a longer maturity than overnight Fed funds, so their yields are not strictly comparable. Since the positive spread of Fed funds over $C D^{\prime}$ 's could have reflected an anticipation of the dramatic decline in Fed funds rates over the period, we investigated the spread for two sub-periods as well. Over the three year period from the beginning of 1984 to year-end 1986, Fed funds rates trended downward, but the decline was slow. During that period, the Fed funds rate exceeded the $C D$ rate (unadjusted for reserve requirements) by 12 basis points. Adjusted for reserve requirements, the $C D$ rate exceeded the Fed funds rate by 14 basis points. Over the two year period from the beginning of 1987 to year-end 1988, the Fed funds rate was rising. The $C D$ rate (unadjusted for reserves) exceeded the Fed funds rate by 7 basis points, on average. In no case was the differential significantly different from zero.

\section{Why Demand Deposits and Fed Funds are substitutes}

In Table $4 \mathrm{a}$ we present the balance sheet of a bank at the end of the business day. There are 1000 in demand deposits, 2000 in CD and 50 in capital funding 950 of overnight Fed funds loans and 1940 of securities. Reserves are 160, $10 \%$ against DD and $3 \%$ against CD. since the business day is over, the customer with demand deposits 
has certain access to the funds at the start of business the next day but has loaned the funds to the bank overnight. The bank then has good funds overnight which it can lend at the Fed funds rate. 21

If it uses the deposit to lend Fed funds, good funds will be returned by the borrowing bank at the start of business next day. Hence, the properties of the Fed funds loan are identical to those of the booked demand deposit. Table 4 depicts the balance sheet at the start of business next day. Reserves have increased to 1110 as the Fed funds are repaid immediately.

The bank would not pay a higher implicit yield on demand deposits than on Fed funds. The demand deposits on its books indicate that customers and the bank both are willing to forego the interest on the $10 \%$ required reserves held against the deposits. Why do banks not bid the Fed funds rate above the DD rate by the cost of holding reserves?

The DD holder has indirect access to the Fed funds market through the use of overnight repurchase agreements with banks. Toward the end of a business day, a customer faced with holding positive end-of-day demand deposits can elect either to leave them in the bank or to enter a repurchase agreement with the bank. In a repurchase agreement, the customer will purchase a government security from the bank at the end of the day, and the bank will buy it back the next morning for a predetermined price. The bank's end

21 Alternatively, having the demand deposit allows the bank to avoid borrowing overnight Fed funds. 
of day balance sheet will have fewer demand deposits by the purchase price of the security, and this will release reserves to lend on the Fed funds market overnight. The next morning, the bank simultaneously receives repayment on the Fed funds and repurchases the security, making the funds available to the customer at the start of business.

Table 5a depicts the end-of-day bank balance sheet if demand deposits are all expended on a repurchase agreement. Demand deposits are now zero, so reserves are only 60. The bank makes an additional 100 in overnight Fed funds loans. A 1000 repurchase liability replaces the demand deposit. Table $5 b$ depicts the start of day bank balance sheet after the Fed funds overnight loans have been repaid on Fedwire and after the bank exchanges a demand deposit credit for its securities to its repo customer. For the bank and for the customer, the start of day position is identical to that of holding a demand deposit overnight.

The repurchase agreement permits the customer to convert its demand deposit into a collateralized Fed funds loan with liquidity properties identical to Fed funds. 22 Both demand deposits and repurchases entail delivery of good funds at the end of the day to the bank for resale on the Fed funds market. Both require the receipt of funds available for expenditure the next morning. From

22 since the repurchase agreement is collateralized while Fed funds are not explicitly guaranteed, repurchase agreement rates are typically somewhat lower than the fed funds rate. To ease clerical problems and transactions costs, however, banks typically ask that the security be deposited with the bank itself. The extent of the guarantee of repayment therefore is questionable. 
the viewpoint of the customer, these are identical claims. If the implicit yield on DD is less than the Fed funds rate, the customer will substitute entirely into repurchase agreements, leaving no demand deposits in the bank.

This discussion leads to a result analogous to the incidence of the cost of reserves on $C D$ and $C P$. Banks cannot charge the reserve cost of demand deposits to the Fed funds borrowers or to the holders of demand deposits. Demand deposits and Fed funds pay the same liquidity premium because they have the same liquidity characteristics.

\section{Rates and Fed Funds Rates}

Since $C D$ is less liquid than demand deposits, it should pay a premium to its holders over the implicit rate on demand deposits, reflecting the costs of reserves held on demand deposits. Since Fed funds are substitutes for demand deposits, $C D$ rates bear a markup over Fed funds rates.

\section{Reserves Are the Most Liquid Asset}

The availability of substitutes for reservable deposits permits banks to reduce reserves to any desired level while still supplying liquid liabilities to the market. 23 since banks issue demand deposits, they must not view reserves as a cost from which they derive no benefit. They hold the level of reserves necessary to supply liquidity to the market. We now consider why banks choose both the amount of reserves that they will hold and their

23 Reserves pushed out of the banks would show up as increased currency holdings. 
structure of reservable liabilities.

clearinghouses allow banks to conserve on the holding of reserves, thereby lowering the cost of delivering good funds. settlement, however, is designed to transfer risk from the clearinghouse back to the individual members, severally. Settlement occurs because of a risk of material change in the creditworthiness of banks. If a member's position deteriorates such that it cannot deliver reserves for settlement of the day's payment orders, the entire clearinghouse loses the reserves necessary to cover that bank's net due to position, which could weaken otherwise strong members of the clearinghouse.

To assure that bank deposits are liquid instruments, periodic settlements must occur. Risk transfer cannot be accomplished completely unless reserves are held in the system. Reserves are the most liquid instrument, whose presence makes credible the guarantee of liquidity to other securities. 24

The Federal Reserve absolutely guarantees delivery of reserves associated with daylight payments, which lays the risk of non-

24 This basic interpretation of reserves was held in the early days of the Federal Reserve system. For example, willis, Chapman, and Robey (1933, p. 257) state: "Thus, the reserve requirement under the Federal Reserve Act is really that there be maintained a net balance between claims upon the banks and those held by it against other banks equal to a given percentage of the claims (deposits) it has agreed to pay, and this balance is the outcome of the clearing which has been described. It represents the net live credit of the banks which make up the Federal Reserve system--the credit which has not become subject to draft as the result of checking by depositors. Reserves in the Federal Reserve sense are thus the proportion of unquestionably liquid claims to total outstanding claims against the members. The Federal Reserve system is thus, in its reserve aspect, a means of testing and assigning credit to those entitled to it." 
settlement on the Fed. If, in addition, they can borrow overnight from the Fed to cover net due to positions, member banks themselves have no apparent incentive to hold reserves to effect risk transfer. To provide an incentive and to compensate itself for the risk it bears, the Fed must limit the use of its overnight loans. The Fed's limit creates a shadow price for borrowing reserves from the Fed, which leads to a contract market in Fed funds lines. To avoid incurring the shadow price at the Fed, a bank participating in the market will pay for Fed funds lines. 25

On any day, a spot seller of Fed funds can apparently provide funds on a line without holding reserves overnight because the Fed guarantees that a liquidity problem on the next day will not prevent the delivery of good funds sent the following morning. This appearance is an illusion, however. To assure the ability of satisfying unusual borrowing demands on lines, the seller must hold some overnight reserves.

As an example, assume that a spot seller of overnight Fed funds arranges several Fed funds lines. Suppose that today it sells all its reserve holdings on the spot market through its committed lines by eliminating all its required reserves through repos with its demand deposit customers. This is its normal practice, so that it never holds reserves on its overnight balance

25 If end-of-day net due to's are the random variable $N$, the level of bank Fed funds lines, $L$, plus borrowings from the Fed, $B$, must be such that $N=L+B$. If the lines pay the Fed funds rate $i_{F F}$ and the Fed's shadow overnight rate is $r_{s}(B)$, the banks establish lines such that the difference between the expected Fed funds rate and the shadow overnight rate equals the covariance between the marginal shadow rate and the level of discount window borrowing. 
sheet. It appears that the cost of making credible the promise to deliver good funds on the line commitments is zero exactly because the Fed guarantees to deliver good funds for all payment orders sent next day. Next morning, its Fed funds customers will deliver the good funds due the seller, which will surely be available because of the Fed's guarantee of Fedwire payments If, next day, its Fed funds line customers wish to increase their borrowing demands under the line to a level higher than normal, the selling bank has no way to fulfill its obligations. To provide a credible guarantee that yet additional Fed funds will be delivered on a line, the seller must hold reserves overnight on its balance sheet; and it will demand compensation for holding them.

\section{A Crisis under a Fractional Reserve Banking system}

In our stylized version of the commercial paper market presented in section 3 , banks held reserves against 1 ines. We have argued that, in practice, they need not hold $100 \%$ reserves against all lines because they are part of a banking system which can mobilize good funds rapidly. Thus, the banking system is a fractional reserve system as measured against the potential demand for reserves to back up lines.

Occasionally, however, there is an increase in the amount of end-of-day net due to's in the banking system, with an associated increase in demand for reserves. How does the system create the increased delivery that is demanded?

The amount of reserves that the banking system chooses to hold 
is determined by the shadow price of borrowing from the Fed. With a sudden increase in demand for reserves, sellers committed to Fed funds lines can respond by substituting for demand deposits nonreservable liabilities with equal liquidity. They can also generate excess reserves by substituting non-reservable paper for $C D^{\prime} s$, though this is not as instantaneous a procedure.

If these actions cannot satisfy the demand, the Fed funds rate will rise. This will cause the liquidity premium on less liquid securities to rise and increase the discount that sellers of securities must suffer to effect settlement in demand deposits. Some potential sellers will decide to hold their securities rather than to sell them for bank deposits. In addition, the Fed funds rate may rise sufficiently to make it profitable to pay the shadow price of borrowing from the Fed, which will increase the amount of reserves in the system.

Finally, the Fed may provide liquidity to the market through open market operations. If the Fed makes it known that it will substantially increase reserves in a crisis, bank holding of reserves will decline in normal times.

\section{When are Reserve Requirements a Tax?}

Reserve requirements associated with the occasional bank funding of securities are paid by both issuers and investors. If reserves really are a tax, the burden is then borne by all participants in the securities markets, including non-bank intermediaries. In this section, we analyze the question of 
whether reserves are indeed a tax on the provision of liquidity. Reserve requirements cannot be a tax if banks would hold the same level of reserves without the requirement. If perfect substitutes are available for reservable deposits, banks can reduce the level of reserves to the desired level regardless of the reserve requirement.

If the clearinghouse or Federal Reserve decides to increase reserve requirements on $\mathrm{DD}$, the cost of settlement in demand deposits increases, which raises liquidity premiums on $C P$ and $C D$. Fewer transactions will be settled in bank deposits and more open market paper will be issued relative to bank loans. The rise in liquidity premiums will be constrained somewhat by the decline in the probability of a demand for settlement in demand deposits because of the increased cost of such settlement.

The reserve requirement is a crucial determinant of the size of the banking system as measured by the end-of-day balance sheet and of the liquidity premium. If the requirement is high, the liquidity premium and the opportunity cost of holding liquid assets will be high. But in what sense is the reserve requirement high? To determine this, we return to our discussion of the private clearinghouse.

The optimal Level of Reserves at the Private clearinghouse

Reserves must at least equal the sum of the end-of-day net due to positions for the private clearinghouse to guarantee absolutely the delivery of good funds at settlement. The cost of the 
guarantee is the foregone interest on the reserves; and to receive the assurance that good funds can be delivered on the day's payment orders, clearing members pay this cost of providing the guarantee. Reserves are not a tax in this situation. 26

Reserves become a tax when a clearinghouse forces its members to hold reserves in excess of those reasonably needed to cover the day's "net due to's". If excessive reserves are required, the price of delivery of funds will rise, forcing up the liquidity premium on yields on market securities. More investors will be willing to forego selling their securities to dealers for bank deposits, because the price of dealer bank finance will rise.

Are Reserves a Tax in the Federal Reserve System?

What is the appropriate level of reserve requirements in the Federal Reserve system? The Fed's guarantee of delivery of reserves at settlement is absolute. Ideally, the Fed should set the reserve requirement such that the income on its portfolio of securities financed by reserves plus income from other charges on member banks for using the payments system covers expected losses from the payments system.

The Fed can mimic the private clearinghouse in this regard. It can set reserves equal to expected end-of-day net due to's and charge a fee for expected losses in reserves. Required reserves in

26 Members of the clearinghouse must bear an additional charge in the event that one of their members fails, so the interest foregone on the reserves does not represent the total cost of the guarantee. Members must assess depositors an additional charge to cover the expectation that they will have to replace reserves. 
the United States are currently about $\$ 59$ billion, of which about $\$ 37$ billion represents bank deposits held at the Fed. An additional $\$ 22$ billion is vault cash held directly at banks for use in the banks' currency business. Net due to positions on Fedwire, CHIPS, and U.S. government securities trading sums to about $\$ 100$ billion a day at some time of the day. Total reserves are then less than the potential due to position during the day, though not at the end of the day. This is below the level that a private clearinghouse would set to provide an absolute payment guarantee. 27

Reserve requirements are not necessarily too low, however. Unlike the private clearinghouse, the Fed earns interest on reserves. Since it can create good funds at will, it can invest the proceeds without worrying about its ability to convert them to good funds to satisfy net due to positions. This income can be viewed as compensation for having to supply additional reserves in the event that an individual bank or group of banks cannot deliver good funds at settlement. The private clearinghouse would have to assess individual members in the event of a failure. The Fed would absorb the loss on daylight overdrafts since it would have to line up as an unsecured creditor.

In summary, reserve requirements cannot be a tax on banks because with perfect substitutes for reservable deposits banks can avoid holding unwanted reserves. In the U.S., bank reserves amount

27 The net due to position in the government securities market is $\$ 40$ billion. If a bank fails to make payment on a government security it has received for its customer, and the Fed delivers reserves as payment to the seller's bank, it is not clear who has claim to the security -- the purchaser or the Fed. 
to about 2 percent of bank liabilities while deposits at the Federal Reserve amount to about 1 percent of liabilities. This is comparable to reserves held against liabilities in other banking systems with much lower reserve requirements. Counting off-balance sheet items, it is comparable to the reserves held by the UK banking system, which lacks explicit reserve requirements.

\section{Conclusion}

In the conventional view, reserve requirements are a tax on the banking system not borne by other intermediaries. The recent literature has focused on bank borrowers as the bearers of the cost of reserves. This has resulted partly from evidence that commercial paper and certificates of deposit trade at the same yields. Commercial paper is not subject to a reserve requirement, while certificates of deposit are. Since they trade at the same yield, certificate of deposit holders cannot bear the cost of reserves. Therefore, bank borrowers must.

We have presented an alternative for how the cost of reserves is borne in financial markets. Commercial paper issuers purchase lines which commit a bank to provide a loan if the issuer cannot roll over the paper at maturity. The bank guarantees that a commercial paper issuer can deliver good funds to the investor at maturity, so the bank supplies liquidity to the commercial paper market.

We have shown that commercial paper issuers pay for reserve requirements to the extent that they expect to borrow against their lines because the use of the line has payment implications for the 
banking system, which expands its desire to hold reserves. Using a similar line of argument, we have shown that the cost of reserves must be reflected in the prices of all securities.

Securities with a bank line trade at lower interest rates than securities with otherwise identical characteristics which lack a line. The difference in yields exactly reflects the expected cost of reserves and represents a liquidity premium.

If a security without a bank line has a low probability of requiring settlement by the delivery of good funds, the expected cost of a bank line and the liquidity premium will be very low. We can then define a liquid security as a security which infrequently settles with the delivery of reservable deposits. Consequently, holders and issuers of these securities pay little of the cost of reserves.

Reserve requirements are not a tax if close subsititutes exist for reservable liabilities. Even without such substitutes, if they are set at the level necessary to guarantee that a banking system can provide settlement in good funds at the end of a day's transactions, they also need not represent a tax. If they are set above this limit, they are a tax; the incidence of the tax, however, falls generally on liquidity in all financial markets rather than on current depositors or borrowers from the banking system. The cost of reserves cannot be a tax on liquidity as long as the market can create instruments which have no reserve requirements while maintaining the same liquidity as reservable deposits. 


\section{References}

Black, Fischer, "Bank Fund Management in an Efficient Market", Journal of Financial Economics, 1975, 2, 323-339.

Fama, Eugene, "What's Different About Banks?" Journal of Monetary Economics 15 (January, 1985), 29-40.

Gertler, Mark, "Financial structure and Aggregate Economic Activity: An Overview," Journal of Money, Credit, and Banking, Vol. 20, no. 3, August, 1988 , Part 2 .

Goodfriend, Marvin, "Money, Credit, Banking, and Payments system Policy," in David B. Humphrey, ed., The U.S. payments system: Efficiency, Risk, and the Role of the Federal Reserve, Kluwer Academic Publishers.

Grossman, S. and M. Miller, "Liquidity and Market structure," The Journal of Finance, Vol. 43, No. 3, July, 1988, 617-634.

James, Christopher, "Some Evidence on the Uniqueness of Bank Loans,", Journal of Financial Economics, 19(1987), 217-36.

Lummer, Scott and John McConnell, "Further Evidence on the Bank Lending Process and the Capital Market Response to Bank Loan Agreements", Working Paper, June, 1989.

Moore, George R., Richard D. Porter and David H. Small, "Modeling the Disaggregated Demands for M2 and M1 in the 1980's: The U.S. Experience", Board of Governors of Federal Reserve, May 12, 1988, working paper.

Willis, H. Parker, Chapman, John, and Ralph Robey, Contemporary Banking, New York: Harper, 1933. 
Figure 1

Conventional Analysis of the Cost of Reserves

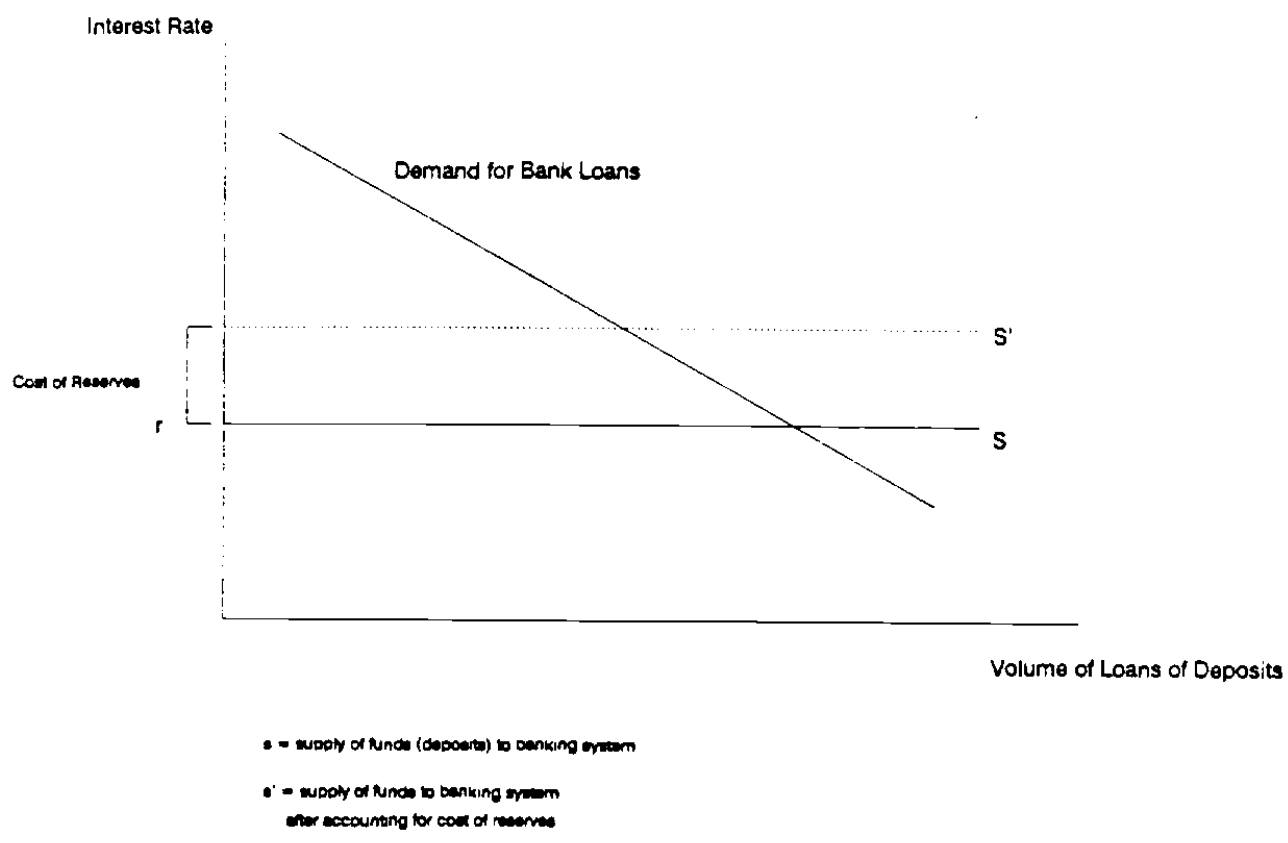


</ref_section> 


\section{Table 1}

(a)

Bank A

\begin{tabular}{c:c} 
Assets & Labilities \\
\hline Reserves 100 & $900 \mathrm{DO}$ \\
Loans 900 & $100 \mathrm{CD}$ \\
&
\end{tabular}

Bank A

\begin{tabular}{c|c} 
Assets & Liabilities \\
\hline Reserves 90 & 90 Due to B \\
Loans 900 & 900 DD \\
&
\end{tabular}

BAnk B

\begin{tabular}{|c|c|}
\hline Assets & Labilities \\
\hline Reserves 70 & $700 \mathrm{DD}$ \\
\hline Laans 540 & \\
\hline Due from A 90 & \\
\hline
\end{tabular}




\section{Table 2}

(a)

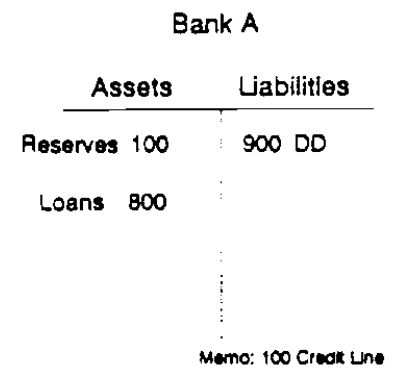

\begin{tabular}{c:c}
\multicolumn{2}{c}{ Bank B } \\
Assets & Labilities \\
\hline Reserves 60 & 600 DD \\
Loans 540 & \\
& $\vdots$
\end{tabular}

(b)

Bank A

\begin{tabular}{c:c} 
Assets & Liabilities \\
\hline Loans 900 & $900 \mathrm{DD}$ \\
& \\
&
\end{tabular}

Bank A

\begin{tabular}{c|c} 
Assets & Labilities \\
\hline Reserves 90 & $900 \mathrm{DD}$ \\
Loans 900 & 90 Due to B
\end{tabular}

BAnk 8

\begin{tabular}{c:c} 
Assets & Liabilities \\
\hline Reserves 160 & 700 DD \\
Loans 540 & \\
&
\end{tabular}

BAnk B

\begin{tabular}{c|c} 
Assets & Liabilities \\
\hline Reserves 70 & 70000 \\
Loans 540 & \\
Due trom A 90 & \\
&
\end{tabular}


Table 3

One Month CD Rate Less Federal Funds Rate

Reserve Adjusted

unadiusted

\author{
1980-88 \\ Average Difference \\ stand. Dev. \\ $1984-1986$ \\ Average Difference \\ stand. Dev. \\ 1987-1988 \\ Average Difference \\ Data source: DRI.
}

$0.18 \%$

$0.70 \%$

$-0.13 \%$

$0.70 \%$

$0.14 \%$

$0.51 \%$

$-0.12 \%$

$0.49 \%$

$0.29 \%$

$0.34 \%$

$0.07 \%$

$0.33 \%$ 


\section{Table 4}

(a)

End of Day-Hold DD

\begin{tabular}{c|c} 
Assets & Labilities \\
\hline Reserves 160 & $1000 \mathrm{OD}$ \\
Fed Funds 950 & $2000 \mathrm{CO}$ \\
Securities 1940 & 50 Capital
\end{tabular}

(b)

Next Morning Fod Funds Pays Off

\begin{tabular}{c:c} 
Assets & Liabilitles \\
\hline Reserves 1110 & $1000 \mathrm{DO}$ \\
Securities 1940 & $2000 \mathrm{CO}$ \\
& 50 Capital
\end{tabular}

\section{Table 5}

(a)

End of Day-Use RP

\begin{tabular}{c:c} 
Assets & Labilittes \\
\hline Reserves 60 & 1000 Repo \\
Fed Funds 1050 & $2000 \mathrm{CD}$ \\
Securities 1940 & 50 Capital \\
&
\end{tabular}

(b)

Next Morning Fed Funds Pays Off

\begin{tabular}{c:c}
\hline Assets & Labilities \\
\hline Reserves 1110 & $1000 \mathrm{CD}$ \\
Securities 1940 & $2000 \mathrm{CD}$ \\
& 50 Capital
\end{tabular}

